\title{
Students' Strengths, Weaknesses, and Causes of Weaknesses in the TOEFL-LIKE Structure Subtest: A Study at STKIP PGRI of West Sumatera
}

\author{
Mayuasti, S.Pd., M.Pd. \\ STKIP PGRI Sumatera Barat \\ E-mail: mayuasti@gmail.com
}

\begin{abstract}
Penelitian ini bertujuan untuk mengidentifikasi menganalisa kelebihan, kelemahan dan penyebab kelemahan pada setiap variabel yang ada pada test TOEFL, khususnya bahagian tata bahasa. Penelitian ini bertujuan memberi kontribusi baik bagi mahasiswa maupun dosen dalam merancang pengajaran tata bahasa, terutama kelas Advanced Grammar yang mempelajari tes tata bahasa pada TOEFL. Hasil penelitian mengungkapkan bahwa kemampuan terbesar mereka terletak pada variabel agreement (81.73\% tingkat kebenaran). Sedangkan kelemahan terbesar yang dihadapi oleh sampel adalah pada variabel auxiliary verb (30.76\% tingkat kebenaran). Ditemukan bahwa False concept hypothesized merupakan penyebab utama kelemahan sampel pada kemampuan tes tata bahasa TOEFL. Maksudnya adalah mahasiswa salah dalam memahami konsep bahasa target yang mereka pelajari.
\end{abstract}

Key Words: Strengths, Weaknesses, Causes of Weaknesses, TOEFL-Like Structure Subtest

\section{INTRODUCTION}

TOEFL is designed to evaluate the proficiency of the English learners. It is developed to be the standard of English proficiency for all English native speakers in the United States. Nowadays, TOEFL is used to be the standard of English proficiency for English non-native speakers, including Indonesian. Many universities and colleges in Indonesia, including STKIP PGRI of West Sumatera, decide TOEFL as one of requirements to pass the Bachelor program, especially for English Department. English Department students who will graduate have to take TOEFL as one of the requirements to get the Bachelor degree. They have to take the TOEFL test before graduating from their Bachelor program.

However, it is not easy to get a high TOEFL score. Based on the data from STKIP PGRI of West Sumatera, from 52 test takers of English Department students, only 11 test takers got TOEFL score above 400 as the minimum score in Mei 2010. From another data in September 2010, only 10\% from the test takers got TOEFL score higher than 400. It can be shown that the English students have difficulty to achieve the high TOEFL score.

The difficulty in getting the high TOEFL score is caused by a problem in grammar. It is proved that the students can only achieve 29 as the highest score for the TOEFL structure section. Meanwhile, according to ETS Hand Book (2010) the score must be at least 31. Sukur (2007) says that the primary problem of the TOEFL test takers is the acquisition of grammar. It makes all TOEFL sections hard to be accomplished. 
Relating to the grammar acquisition problem, as one of the lecturers who teaches grammar; the researcher finds from the students' grammar test results that English Department students of STKIP PGRI have difficulty to decide which component as noun, verb, adjective, or adverb. In addition, they have difficulty in determining where the particular of speech (noun, verb, adjective, or pronoun,) must be placed in a sentence. These weaknesses influence their performance in the TOEFL test, especially for the structure subtest.

The researcher also interviewed the other lecturers who teach grammar. Based on their explanation, it was found that the most of the students got low score in the structure test. It is difficult for the students to understand the concept and the function of each structure variable. Moreover, the students have difficulty in making relationship between a particular of speech with another.

Because of that, the researcher wants to conduct a research in order to find the English students' strengths and weaknesses in the TOEFL structure subtest. By knowing their strengths, and weaknesses in the TOEFL structure subtest, it is useful to identify what particular of structure variable must be improved in order to increase their structure ability and their TOEFL performance.

\section{REVIEW OF RELATED LITERATURE}

\section{TOEFL Structure Subtest}

As stated before, structure subtest is the second section of TOEFL. It consists of two types of questions. The first part asks the test takers to complete the sentences given. The second part asks the test takers to find the wrong word or phrase in the complete sentences given. All of the questions are multiple choices, and every question has only one answer.

Sharpe (2007: 83) says that there are 40 questions that must be answered by the test takers for the Structure section. The test takers have 25 minutes to accomplish this section. In the first part, 15 incomplete sentences will be seen. Each sentence consists of four possible answers. The test takers will be asked to choose the best answer. In the second part, 25 incorrect sentences with four underlined words or phrases marked (A), (B), (C), (D) will be given. The test takers must choose one of the word or phrase that has to be changed to correct the sentence.

There are some variables of the structure subtest that are tested in TOEFL. The variables are explained in all TOEFL preparation books such as Sharpe (2005), Sharpe (2007), Sukur (2007), Walter (2008), and ETS Handbook (2010). All of the theorists have the same idea about the variables that are tested in the TOEFL structure subtest. Because of the reason, the researcher can conclude that the variables of the TOEFL structure subtest as follow:

\section{a. Verbs}

Verb is the most problem of sentences in the Structure Section. The verb can be classified as transitive, intransitive, and complement such as nouns, pronouns, adjective, and adverbs. The test takers will be asked to choose the correct verb from the four possible verbs. 
For example:

To relieve pain caused by severe burns, prevent infection, and treat for shock, ......... immediate steps.
A. taking
B. to take
C. taken
D. Take

The correct answer is D. This sentence needs an expression of a manner to accomplish a purpose, because of that the verb that is intended to complete the sentence is an infinitive.

\section{b. Auxiliary Verbs}

Be, Have, or modal are the examples of auxiliary verbs. Test takers will be asked to select the correct auxiliary verb to accompany with the main verb.

For example:

On the average, a healthy heart to pump five tablespoons of blood with every beat.
A. must
B. ought
C. can
D. Should

The correct answer is B, because ought is used before to to express obligation. Choices $\mathrm{A}, \mathrm{C}$, and $\mathrm{D}$ are modals that are used before verb words, not before to.

\section{c. Nouns}

A noun is a word that names persons, objects, and ideas. Nouns are classified into countable and uncountable nouns. In the structure section, the test takers will be asked to identify the correct noun.

For example;

The two main ..... are permanent magnets and electromagnets.
A. kinds of magnets
B. kind of magnets
C. kind magnets
D. kinds magnets

The correct answer is A, because the sentence needs a plural count noun.

\section{d. Pronouns}

A pronoun is a word that can be used to indicate a noun. It may be used as the subject, object, or preposition of a sentence. The test takers will be asked to choose the correct pronoun for the incomplete and incorrect sentences.

\section{For example:}

The crime rate has begun to decline in New York city due to efforts on the part of both government and private citizens to curb ......
A. them
B . him
C. its
D. It

The correct answer is D. The objective antecedent is crime rate. It is an abstract noun, so the pronoun must be it. 


\section{e. Modifiers}

A modifier can be an adjective or an adjectival phrase that describe a noun or an-ing form. Also, it can be an adverb or adverbial phrase. The test takers will be asked to identify the correct modifier.

For example:

Uranus is just ..... to be seen on a clear night with the naked eye.
A. bright enough
B. enough brightly
C. as enough bright
D. bright as enough

The correct answer is A. An adjective is used before enough to express sufficiency.

\section{f. Comparative}

A comparative expresses the degree of comparison by using adjectives and adverbs. The test takers will be asked to identify the correct comparative to express the similarity or difference.

For example:

1. The seed heads of teasel plants raise the nap on coarse tweed cloth ..... than do the machine tools invented to replace them.
A. more efficiently
B. efficiently
C. more efficient
D. most efficient

The correct answer is C. The comparative of a three-syllable adverb is formed by using more before the adverb and than after the adverb.

2. The New York City subway system is the most longest underground
A
B
C

railroad operating in the world.

D

The wrong underlined word is $\mathrm{B}$. The most longest should be the longest. Because long is a one-syllable adjective, the superlative is formed by adding -est. Most is used with two-syllable adjective that do not end in $-\mathrm{y}$.

\section{g. Connectors}

A connector is a word or phrase that joins words, phrases, or clauses. In the second section of TOEFL, the test takers will be asked to choose the correct connector in order to show the relationship or the sentence such as cause and result, contradiction, substitution, addition, exception, example, and purpose.

For example:

1. Desert are often formed ..... they are cut off from rain-bearing winds by the surrounding mountain ranges.
A. because
B. in spite of
C. so
D. due to

The correct answer is A. Because is used before a subject and verb to introduce cause. 
2. Only seventeen on one hundred business calls get through to the concert

A

person on the first attempt

$\mathrm{D}$
B

C

The wrong underlined word is A. The correct answer is in, because in is used between numbers to express a fraction.

\section{h. Sentences and Clauses}

In some sentences in the Structure Section, the test takers will be asked to distinguish between a sentences, also called a main or independent clause, and a subordinate or dependent clause that is attached to a sentence.

For example:

The jet strem ..... usually occurs at about thirty-five to sixty degrees latitude.
A. a narrow band of wind that
B. is a narrow band of wind that
C. a narrow band of wind
D. it is a narrow band of wind that

The correct answer is B. Choice B is the main clause that introduces a dependent clause.

\section{i. Point of View}

Point of view is the relationship between the verb in the main clause of a sentence and other verb, or between the verbs in a sentence and the adverbs that express time. The test takers will be asked to identify errors in point of view. This type of concept usually find in the second part of the structure section.

For example:

1. Before the 1800s, when William Young made different shoes for right and left feet, shoes ..... on either foot.
A. can wear
B. are wearing
C. could be worn
D. worn

The correct answer is C. The adverbial phrase Before the 1800s establishes a point of view in the past. The modal could in choice $\mathrm{C}$ maintains the point of view.

2. Cartographers cannot make an accurate map because the political situation in many areas changes so rapidly that they were not able to draw
A
$\mathrm{B}$
C

the boundaries correctly.

D

The wrong underlined word is B. The verb cannot make establishes a point of view in the present. Were should be are to maintain the point of view.

\section{j. Agreement}

Agreement is the relationship between a subject and the verb or between a pronoun and noun, or between a pronoun and other pronoun, or between a part of speech and 
another part of speech. The test takers will be asked to identify errors in agreement. It usually appears in the second part of the structure section.

For example:

1. Nine of every ten people in the world ..... in the country in which they were born.
A. living
B. they are living
C. lives
D. live

The correct answer is $\mathrm{D}$. There must be an agreement between subject and verb. Live in choice $\mathrm{D}$ agrees with the plural subject nine of every ten people.

2. Benjamin Franklin strongly objected to the eagle's being chosen as the

A B

national bird because of their predator nature.

$\mathrm{C}$

$\mathrm{D}$

The wrong form is $\mathrm{D}$. There must be an agreement between pronoun and antecedent. Their should be its to agree with the third person singular neuter noun the eagle.

\section{k. Introductory Verbal Modifier}

Introductory verbal modifiers are -ing forms, participles, and infinitives. A phrase with an introductory verbal modifier occurs at the beginning of a sentence and is followed by a comma. The test takers will be asked to determine errors in introductory verbal modifiers and the subjects that they modify.

For example:

1. Written by Neil Simon, New York audiences received the new play

A

B

enthusiastically at the world premiere Saturday evening.

C

$\mathrm{D}$

The wrong form is B. An introductory verbal phrase followed by a comma should immediately precede the noun that it modifies. New York audiences received the new play should be the new play was received by New York audiences because the play, not the audiences, is modified by the verbal phrase written by Neil Simon.

2. The largest hotel on the earth,

A. the MGM Grand has 91 elevators and 5005 rooms

B. there are 91 elevators and 5005 rooms in the GMG Grand

C. 91 elevators and 5005 rooms are in the GMG Grand

D. it is the MGM Grand that has 91 elevators and 5005 rooms

The correct choice is A. An introductory phrase should immediately precede the noun that it modifies. Only choice A provides a noun the could be logically modified by the introductory phrase The largest hotel on the earth. 


\section{Parallel Structure}

Parallel structure is the use of the same grammatical structures for related ideas of equal importance. Related ideas of equal importance often occur in the form of list that are connected by conjunction, such as and, but, and or. The test takers will be asked to figure out errors in parallel structure.

For example:

1. Microwaves are used for cooking, telecommunications, and ........

A. to diagnose medically B. medical diagnosing

C. diagnosed medically D. medical diagnosis

The correct answer is D. Ideas in a series should be expressed by parallel structure. The noun medical diagnosis in choice $\mathrm{D}$ provides parallelism with the nouns cooking and telecommunications.

2. Snakes stick out their tongues, move them around, and also they retract

A

B

C

them quickly to pick up odor molecules that aid in detecting direction.

$\mathrm{D}$

The wrong form is C. ideas in a series should be expressed by parallel structures. Also they should be deleted to provide parallelism among the verb words stick out, move, and retract.

\section{i. Redundancy}

Redundancy is the unnecessary repetition of words and phrases. The test takers will be asked to identify errors in redundancy.

For example:

1. Some international students use a cassette recorder to make tapes of

A B

their classes so that they can repeat the lectures again.

C

$\mathrm{D}$

The wrong concept is D. Repetition of a word by another word with the same meaning is redundant. Again should be deleted because it means repeat.

2. If one does not pick up the dry cleaning within thirty days, the A B management is not obligated to return it back.

C

$\mathrm{D}$

The wrong form is D. Back should be deleted because its meaning is same with return. 


\section{i. Word Choice}

Word choice is the selection of words that express the exact meaning of an idea. Sometimes it is necessary to make a choice between words that are very similar in appearance but very different in meaning. The test takers will be asked to identify errors in word choice.

For example:

The condition of menkind has been improved by recent technological

$$
\text { A } \mathrm{B} \quad \mathrm{C} \quad \mathrm{D}
$$

advances.

The wrong choice is A. Menkind is not idiomatic. Menkind should be mankind or humankind.

From the description above, the researcher can conclude that around fourteen variables are tested in the TOEFL structure subtest. All variables can occur in the same time at the TOEFL, or only some of variables are appeared in the test. Each variable has specific purpose of testing structure ability.

Because of this research also wanted to identify the causes of students weaknesses in answering TOEFL structure subtest, it is needed to provide the theories of the causes of students that might produce errors in their structure ability.

\section{Causes of Errors}

It is natural that something can happen because of some causes. Errors happen because some of causes. Ellis (2003: 59) the causes or errors contributes to the students' weaknesses in acquiring a target language. Richards (1992: 127) tries to classify errors by the causes. According to him, there are four causes of errors. They will be described as follows:

1. Overgeneralization: it is kind of structure generalization mistake. It generally involves the creation of one deviant structure in place of two regular structures. For example: She can makes a cake instead of She can make a cake.

2. Ignorance rule restriction: it is caused by the failure to observe the restriction of structure. For example: I saw the man, and she wore a blue jacket instead of I saw the man, and he wore a blue jacket.

3. Incomplete application of rules: it is caused by the incomplete of the rules applied it. It could be happen because eliciting a part of speech that completes a sentence. For example: He doing his homework right now instead of He is doing his homework right now.

4. False concept hypothesized: it is a class of development error which comes from faulty comprehension of distinction in the target language. It means something due to incomplete gradation of teaching items.

For example: One day it was happened instead of One day it happened. 
In another book, Richards (1997: 120) divides the causes of error into six types. It can be seen from the following explanation.

1. Interference

It is an error resulting from the transfer of grammatical or stylistic elements from the source of language to the target language. For example: the lady beautiful instead of the beautiful lady. It could be happen because the students transfer their Indonesian form that places an adjective after a noun.

2. Overgeneralization

It is an error caused by extension of target language rules to areas where they do not apply. For example: two cans of butters instead of two cans of butter. It can be seen, the students generelize that all nouns can written in a plural form.

3. Performance Error

It is an unsystematic error that occurs as the result of such thing as memory lapses, fatigue, confusion, or strong emotion. Someone who is in an emotional condition such as angry cannot produce a sentence or an utterance correctly.

4. Markers of Transitional Competence

It is an error that results from a natural and inevitable development sequence in the second language learning process by analogy with first language acquisition.

5. Strategy of Communication and Assimilation

It is an error resulting from the attempt to communicate in the target language without having completely acquires the grammatical form. It means full information of the target language is not given in the learning process.

6. Teacher-Induced Error

It is an error resulting from pedagogical procedures contained in the text or employed by the teacher. It indicates that the teacher as the center of the teaching process gives incorrect language input.

Furthermore, Norrish in Hasyim (2002: 47) classifies causes of error into three types that are carelessness, first language interference, and translation. The three types of causes of error will be discussed brieflty below.

1. Carelessness

Carelesness is often closely related to lack of motivation. It could be happen because less interest in the material or style presentation.

2. First Language

Norrish states that learning a language is a matter of habit formation. When someone tries to learn new habits, the old ones will interfere the new one. This cause of error is called first language interference.

3. Translation

Translation is one of the causes of error. This happen because a student translates his first language sentence or idiomatic expression into the target language word by word.

Meanwhile, Stenson in Ellis (2003: 60) states that there are two causes of error in using a target language. The first cause is faulty explanation of grammatical points. It means the students get a wrong explanation about the concept of the target language. The second cause is drill performed without consideration for meaning. It indicates that the students are only asked to do the structure exercises without concerning on the meaning of the 
particular of speech in a sentence. In another words, the exercises only focus on the syntactical rules.

In conclusion, there are some causes of errors in using the target language. The causes of error produce students' weaknesses in using the target language. Based on Richards (1992), the errors might happen because overgeneralization, ignorance rule restriction, incomplete application rules, and false concept hypothesized. Moreover, Richards (1997) divides the causes of errors into interference, overgeneralization, performance errors, markers of transitional competence, strategy of communication and assimilation, and teacher-induced error. On the other hand, Norrish in Hasyim (2002) classifies causes of error into three types that are carelessness, first language interference, and translation. Meanwhile, Stenson in Ellis (2003) states that the causes of error are fauly explanation of grammatical points and drill performed without consideration for meaning. Among all causes of errors, the researcher chooses the causes of errors proposed by Richards (1992). It is because the Richards' theory is mostly related with this research, which found the causes of weaknesses in using structure variables in a sentence.

\section{METHODOLOGY}

\section{Design of the Research}

This study was conducted by using a descriptive research. In this particular work, the researcher investigated and identified the abilities of English Department students of STKIP PGRI of West Sumatera in the TOEFL structure subtest.

\section{Subject of the Research}

This research was conducted in the English Department of STKIP PGRI of West Sumatera. The subject of the research was the third year students in academic year 2010/2011 who have accomplished Grammar I, II, III, and Advanced Grammar. They were divided into 14 classes (2008 A-M). Around 35 students join each class. It means the total population was around 455 students. Because the total of the subject was too large, the researcher took $10 \%$ of the students randomly. The researcher rolled 35 numbers of papers. After that, four numbers of paper were taken randomly. The process was done for all classes. The chosen number of each class based on the attendance list would be the subject of the research.

\section{Instrumentation}

The instrument of the research was a test. The test given was the Structure and Written Expression of the TOEFL test used in STKIP PGRI of West Sumatera. Based on the information from the Head of English Department of STKIP PGRI of West Sumatera, this test was a standardized test because it was constructed by adopting, and adapting the TOEFL test from several TOEFL Institutions such as ITP, and ITI. Also, the test was taken from some standardized TOEFL books such as Barron, and Cambridge. Furthermore, the test has been used for testing English Department students who are going to graduate.

The test consisted of 40 questions that distributed in three pages. The test takers had to answer those questions in 45 minutes. From structures variables that suggested by 
all TOEFL books in the chapter two, pronoun; sentence and clause; introductory verbal modifier; redundancy; and word choice were not included in the TOEFL structure subtest used by STKIP PGRI of West Sumatera. Because of that the researcher modified the test by replacing some dominant questions (verb, point of view, and parallel structure) with another questions (pronoun, sentence and clause, introductory modifier, redundancy, and word choice).

Because the test was modified, it was needed to find the item difficulty of the test. From the calculation, it was found that the score was 0.82 . It can be concluded that the test had very high correlation of reliability. It indicated that the test could be used as the instrument of the research.

\section{Technique for Gathering Data}

The data was taken from the sample's score of Structure and Written Expression test of TOEFL. The test was given twice to get the students' scores. The second test was given one week after the first test. To determine their average score, the result of the first and the second test was divided by two. The students' results determined which sub skills were acquired or not by the students.

\section{Technique of Data Analysis}

1. The researcher calculated the percentage of students' strengths and weaknesses of each structure variable. The researcher analyzed the total strengths and weaknesses of each structure variable by using percentage formula.

Before analyzing the percentage of strength and weaknesses of each structure variable, the writer found the percentage of distribution and frequency made in each structure variable. The formula used is suggested by Sudjana (1984).

To find the total percentage of distribution of each structure variable, the formula was:

$$
P=\frac{S E}{\sum T D} \times 100 \%
$$

To find the total percentage of frequency of each structure variable, the formula was:

$$
P=\frac{S E}{\sum T F} \times 100 \%
$$

$$
\text { where: } \begin{aligned}
\mathrm{P} & =\text { Total Percentage } \\
\mathrm{SE} & =\text { Number of distribution or frequency } \\
\sum \mathrm{TD} & =\text { Number of total distribution } \\
\sum \mathrm{TF} & =\text { Number of total frequency } \\
\mathrm{P} \sum \mathrm{TD} & =\text { The result of percentage distribution } \\
\mathrm{P} \sum \mathrm{TF} & =\text { The result of the percentage frequency }
\end{aligned}
$$

2. The researcher explained the students' strengths and weaknesses by presenting the percentage of correctness and falseness of each TOEFL structure variable. 
3. The researcher explained the degree of seriousness of students' strengths and weaknesses by grading the percentage of correctness and falseness of each TOEFL structure variable.

Meanwhile, the data of interview was analysed by the procedures below:

1. The researcher wrote the transcript of the students' answers.

2. The researcher translated the trancription into English.

3. The researcher interpreted and analysed the data interview in order to find the causes of the students' weaknesses in answering TOEFL structure variables.

\section{FINDINGS}

1. Students' strengths in the TOEFL structure subtest

Besides showing the students' abilities, students' strengths were described. From fourteen TOEFL structure variables, "Agreement" was the variable mostly answered correctly by the students. From 52 students, 51 students could answer the "Agreement" correctly. Nearly all of them answered all the questions of "Agreement". It was proved that the students were able to identify the relationship between a subject and the verb or between a pronoun and noun, or between a pronoun and other pronoun. Moreover, the students could identify errors in agreement. Another TOEFL structure variable could be answered by the students was "Sentence and Clause". There were 51 students could answer all the questions of "Sentence and Clause". It means that the students were able to distinguish between a sentence, also called a main or independent clause, and a subordinate or dependent clause was attached to the questions. The following TOEFL structure subtest acquired by the students was "Redundancy". There were 48 students answered "Redundancy" correctly. From two questions of "Redundancy', the average of one could be answered. It was shown that the students could identify errors in redundancy whether unnecessary repetition of words and phrases.

The strength of the students can be seen from the following table.

Table 1

The Tabulation of Students' Strengths in the TOEFL Structure Subtest

\begin{tabular}{|c|c|c|}
\hline Level of Strength & Variable & Percentage of Correctness \\
\hline 1 & Agreement & $81.73 \%$ \\
\hline 2 & Sentence and Clause & $75 \%$ \\
\hline 3 & Redundancy & $67.30 \%$ \\
\hline 4 & Pronoun Comparative & $65.38 \%$ \\
\hline 5 & Parallel Structure & $63.94 \%$ \\
\hline 6 & Verb & $57.05 \%$ \\
\hline 7 & Word Choice & $55.76 \%$ \\
\hline 8 & Noun & $54.48 \%$ \\
\hline 9 & Point of View & $53.84 \%$ \\
\hline 10 & Modifier & $50 \%$ \\
\hline 11 & Connector & $48.07 \%$ \\
\hline 12 & Introductory Verbal Modifier & $45.19 \%$ \\
\hline 13 & Auxiliary Verb & $30.76 \%$ \\
\hline
\end{tabular}


2. Students' weaknesses in the TOEFL structure subtest

After getting the students' strengths, the data also described the weaknesses of the students in the TOEFL structure subtest. From the data it can be shown that "Auxiliary Verb" was the most problem. There were only 30 students could answer the questions. They only answered the average of one of the two "Auxiliary Verb" questions. It indicated that it was hard for the students to select the correct auxiliary verbs (be, have, or modal) to accompany with the main verb. The following variable difficult to be answered was "Introductory Verbal Modifier". From 52 students, 41 students answered the questions correctly in the average of one from two questions. It was shown that to determine errors in introductory verbal modifiers (-ing forms, participles, and infinitive) and the subject that they modify was difficult for the students. Besides those two variables (Auxiliary verb and Introductory Verbal Modifier), "Connector" was another students' weakness. There were 49 students answered correctly the average of two from two questions. It could be seen that it was still difficult for the students to choose the correct connector in order to show the relationship of the sentence such as cause and result, contradiction, substitution, addition, exception, example, and purpose.

\section{The causes of students' weaknesses in the TOEFL structure subtest}

Besides giving the TOEFL structure subtest for the students, an interview was also done by the researcher in order to identify the causes of students' weaknesses based on the students' point of view. The students who got the low score were as the interviewees. There were six students chosen randomly. The researcher asked the students what were their difficulties in answering the questions of each TOEFL structure variable. Based on the interview, the researcher got some causes of the students' weaknesses in the TOEFL structure subtest. First, it was found that the most cause of their weaknesses is lack knowledge of each structure variable. It indicated that the students did not get full information of each TOEFL structure variable. It made the students have faulty comprehension of the concept of TOEFL structure variables. Moreover, enough examples and exercises were not provided by the lecturers. Besides, the students themselves did not try to practice and to use the structure variables in their language skills. Furthermore, lack of vocabulary was still as their reason why they could not understand the questions given. Last, their reading ability also gives contribution to their weaknesses in answering the questions of TOEFL structure subtest.

The tabulation of the students' weaknesses in the TOEFL structure subtest and the causes can be seen from the following table. 
Table 2

The Tabulation of Students' Weaknesses and the Causes of the Weaknesses in the TOEFL Structure Subtest

\begin{tabular}{|c|c|c|c|}
\hline $\begin{array}{l}\text { Level of } \\
\text { Strength }\end{array}$ & Variable & $\begin{array}{l}\text { Percentage } \\
\text { of falseness }\end{array}$ & $\begin{array}{c}\text { Causes of the } \\
\text { weaknesses }\end{array}$ \\
\hline 1 & Auxiliary Verb & $69.24 \%$ & $\begin{array}{l}\text { False concept of } \\
\text { hypothesized }\end{array}$ \\
\hline 2 & $\begin{array}{c}\text { Introductory } \\
\text { Verbal Modifier }\end{array}$ & $54.81 \%$ & $\begin{array}{l}\text { False concept of } \\
\text { hypothesized }\end{array}$ \\
\hline 3 & Connector & $51.93 \%$ & $\begin{array}{l}\text { False concept of } \\
\text { hypothesized }\end{array}$ \\
\hline 4 & Modifier & $50 \%$ & $\begin{array}{l}\text { False concept of } \\
\text { hypothesized }\end{array}$ \\
\hline 5 & Point of View & $46.16 \%$ & $\begin{array}{l}\text { Ignorance rule } \\
\text { restriction }\end{array}$ \\
\hline 6 & Noun & $45.52 \%$ & Overgeneralization \\
\hline 7 & Word Choice & $44.24 \%$ & $\begin{array}{ll}\text { a. } & \text { False concept of } \\
& \text { hypothesized } \\
\text { b. } & \text { Ignorance rule } \\
& \text { restriction }\end{array}$ \\
\hline 8 & Verb & $42.95 \%$ & $\begin{array}{l}\text { False concept of } \\
\text { hypothesized }\end{array}$ \\
\hline 9 & $\begin{array}{c}\text { Parallel } \\
\text { Construction }\end{array}$ & $36.06 \%$ & $\begin{array}{l}\text { Ignorance rule } \\
\text { restriction }\end{array}$ \\
\hline 10 & $\begin{array}{l}\text { Pronoun \& } \\
\text { Comparative }\end{array}$ & $34.62 \%$ & $\begin{array}{l}\text { Ignorance rule } \\
\text { restriction }\end{array}$ \\
\hline 11 & Redundancy & $32.70 \%$ & $\begin{array}{l}\text { Ignorance rule } \\
\text { restriction }\end{array}$ \\
\hline 12 & $\begin{array}{l}\text { Sentence and } \\
\text { Clause }\end{array}$ & $25 \%$ & $\begin{array}{l}\text { Incomplete } \\
\text { application rules }\end{array}$ \\
\hline 13 & Agreement & $18.27 \%$ & $\begin{array}{l}\text { False concept of } \\
\text { hypothesized }\end{array}$ \\
\hline
\end{tabular}

\section{CONCLUSION}

In can be concluded that "Agreement" is the most students' strength, and "Auxiliary Verb" is as the most students' weakness. From the data, it can be seen that nearly all questions of "Agreement" can be answered correctly (81.73\% of correctness and 18,27\% of falseness) by the students. However, nearly all of questions of "Auxiliary Verb" cannot be answered correctly (30.76\% of correctness and $69.24 \%$ of falseness) by the students. Hence, most of the falseness is happened because "False concept hypothesized". It means that the students have faulty comprehension of distinction in the target language. 


\section{REFERENCES}

Arikunto, Suharsini. 2005. Dasar-Dasar Evaluasi Pendidikan. Jakarta: Bumi Aksara.

Cummins, Jim. 2000. Language, Power, and Pedagogy: Bilingual Children in the Crossfire. Great Britain: Cambrian Printers Ltd

ETS Handbook. 2010. Formats and Sections of TOEFL. www.ets.org/toefl retrived on July 4, 2010.

Harley, Brigit. 1990. The Development of Second Language Proficiency. Cambridge: Cambridge University Press.

Hughes, Arthur. 2003. Testing for Language Teachers. New York: Cambridge University Press.

Purpura, Enos. 2004. Assessing Grammar. Cambridge: Cambridge University Press.

Sharpe, Pamela J.2005. Barron's How to Prepare for the TOEFL Test; $11^{\text {th }}$ edition. Binarupa Aksara.

Sharpe, Pamela J. 2007. Practice Exercise for the TOEFL (6 ${ }^{\text {th }}$ Edition). New York: The Ohio State University.

Walter, Elisabeth. 2008. Cambridge Advanced Learners' Dictionary (3 ${ }^{\text {rd }}$ edt). London: Cambridge University Press.

Xin, Zhuang. 2008. Practice on Assessing Grammar and Vocabulary: The Case of the TOEFL. US-China Education Review Volume 5, No.7 (Serial No.44). 